\title{
Modality Analysis on the Official Website of Indonesian Tourism
}

\author{
Shafira Rahmasari*, Stefanny Lauwren \\ Universitas Sanata Dharma, Indonesia \\ *Email: rahmasari_shafira@yahoo.com
}

DOI https://doi.org/10.15294/lc.v15i1.24453

Submitted 14 May 2020. Revised 7 August 2020. Accepted 19 September 2020

\begin{abstract}
Tourism is believed as the primary motivation to improve the economy of a country. In order to attract some tourists to visit tourism destinations in Indonesia, The Ministry of Tourism establishes an official website to share the information regarding the tourism destinations, activities, and attractions. This study is conducted to observe how the official website of Indonesian tourism utilizes modality to present Indonesian tourism discourse. This paper analysed ten destination highlights of the website covering the areas of Medan, Raja Ampat, Bali, Banyuwangi, Bintan Island, Jakarta, Yogyakarta, Bandung, Makassar, and Lombok through Discourse Analysis approach utilizing Halliday's Systemic Functional Linguistics. This paper found modality is used in the forms of probability, usuality, inclination, and obligation. Those different types of modality are employed to describe three domains of tourism discourse: itineraries and access, place to play, and authenticity. It is concluded that the government uses the website to ensure the readers' being well informed of Indonesian tourism destinations and safety during their visit to Indonesia.
\end{abstract}

Keywords: modality; tourism discourse; discourse analysis

\section{INTRODUCTION}

Indonesia is known as the largest archipelago country with more than 13,000 islands whose two third of the area is water (Pranita, 2018). Within the area either in the land or in the water, it has ecosystem and species diversity (Chairiyah, 2013). The ecosystem and species diversity are wide as well as the cultural diversity. According to Chairiyah (2013), the ecosystem and cultural diversity are potential to attract tourists to visit an area. The use of brochures, booklets, websites and social media platforms are commonly found to promote tourism destinations.

Over two decades the tourism industry in Indonesia has undergone substantial change because of economic change during the period (Suparwoko, 2011). It is said that touristic activity generates significant economic benefit for the country and the tourists as well (Cholic, 2017) as Indonesia is a developing country (Dewi et al., 2018). Cholic (2017) argues that one of the primary motivations for a developing country to promote itself is the economic improvement mainly through foreign exchange earnings including tourism industry. Therefore, The Ministry of Indonesian Tourism establishes an official websi- te to share the information regarding the tourism destinations, activities, and attractions to attract people to visit the places.

Jaworski and Pritchard (2005) state that tourists imagine and shape their expectation about the destination long before they arrive at that place. Thus, through websites, it helps the tourist imagine the destination as the process of preparation and anticipation (Jack and Phipps, 2005). Some photos of the tourism places or attractions are displayed on the website. To elaborate the detail in the photo, they put the information on articles. On the websites it is composed of some texts that construct the identity of the destination that is both indicative and inviting (Hallett and Kaplan-Weinger, 2010). Hallett and Kaplan-Weinger (2010) argue that the text which narrates the destination is produced through the interaction between the web user, the web text and the website creator.

Tourism discourses can be defined as a set of expressions, words and behavior as well as particular touristic structures and activities that describe a place and its inhabitants (Jaworski \& Pritchard, 2005). Thus, the text that is used in the tourism website contains tourism discourses, as they are used to express, describe, and construct 
the desired image of the destination. The text will help the tourist assemble different images and ideas of the destination.

This research focuses on how the official website of Indonesian tourism utilizes modality to present Indonesian tourism discourse. Modality enables the researchers to reveal how Indonesian governments exchange information, goods and services. On the front page of the website, there are ten destination highlights providing some areas along with their information. Accessed in January 2020, the ten destination highlights consist of Medan, Raja Ampat, Bali, Banyuwangi, Bintan Island, Jakarta, Yogyakarta, Bandung, Makassar, and Lombok.

Systemic Functional Linguistics (SFL) argues that the ultimate goal of using language is not just to communicate but to get the right meaning across and accomplish certain social purposes (Endarto,2017). Therefore, language is used in the text, in this case articles, to engage the reader and it is used to study what is beyond the words. The language use might range from the choice of words, the syntactic structure of the clauses and sentences, to the organization of the texts (Manggala, 2017). Manggala (2017) also argues that their personal background, understanding as well as their belief influence the reproduction of using language.

Systemic Functional Language (SFL) is used to support this study since it has been used by many researchers to analyze texts and to discover the meaning of the text by analyzing the use of grammar. SFL is a tool to find out the ideologies of a text. There are three metafunctions in Halliday's Systemic Functional Language: ideational, interpersonal, and textual (Halliday, 2014).

Ideational Metafunction is the function that construes human experience. It is distinguished into two components; experiential and logical. It construes a quantum of change in the flow of events as a figure, or configuration of a process, participants involved in it and any attendant circumstances. Interpersonal metafunction deals with how information, goods and services are exchanged. Textual metafunction focuses on the quantum of information in the flow of discourse: it has some form of organization whereby it fits in with and contributes to, the flow of discourse (Halliday \& Matthiessen, 2014).

Interpersonal metafunction connects the relationship between the speaker and the audience. One of linguistic tools in interpersonal metafunction is modality. It is a complex area of English grammar that has to do with the different ways in which a language user can intrude on their message, expressing attitudes and judgement of various kinds (Eggins, 2004). Modality is thus grounded in the initiating role of an exchange (Halliday, 2004). Eggins (2004) explains that there are two types of modality which are modalization and modulation.

Modalization is used to argue about the probability or frequency of prepositions. Thus, it is classified into probability and usuality. Probability is used to express judgement as to the likelihood or the probability of something happening or being happened. On the other hand, usuality occurs to express the judgment of frequency in which something happens. It can be expressed through a finite modal operator in the verbal group or a modal adjunct (Halliday, 2004). On the other hand, modulation is used to argue about the inclination or obligation of proposal (Eggins, 2004).

Inclination is used to represent the tendency of a speaker to do something as well as the capability from their own feeling while obligation is used when the speaker is about giving command, suggestion, demand or advice to the listener. It is expressed in a form of a finite modal operator or an expansion of the predicator through verbal group complexing such as in a form of a passive verb or an adjective (Halliday, 2004). The degree of modalization and modulation are affected by the status, contact, and affect.

Modality is marked by the auxiliaries in which it is covering such notions as probability, usuality, obligation, and inclination. The auxiliaries are called as modal operators in which they are the elements to express the modality in the clause. According to Halliday (2004), probability and usuality can be expressed through finite modal operators in the verbal group such as 'will' and through a modal adjunct for instance the word 'probably' and 'usually'. In addition, both of them can be combined together.

On the other hand, both obligation and inclination can be expressed through a finite modal operator and verbal group (Halliday, 2004). The word 'should', for instance, is a finite modal operator while the adjective such as 'anxious' can be a sign to express an obligation or inclination (Halliday, 2004). Halliday (2004) also argues that passive verbs marked an obligation or an inclination. By using the modal operators or the auxiliary, it depicts the certainty of the utterance which is classified into low, median, and high category.

Similar to modal operator, modal adjuncts are also classified into low, median and high degree. Eggins (2004) classifies the words such as 'might', 'possibly', and 'sometimes' into low cate- 
gory while the words 'may', 'probably', 'usually' belong to the median category. The words such as 'must', 'certainly', 'always' belong to a high category.

Many scholars have studied tourism discourse and modality. Isti'anah (2019) conducted a research by taking an article from the official website of Indonesian government. The researcher focused on the way the official website of Indonesian tourism uses the Indonesian nature to represent Raja Ampat tourism. Critical Discourse Analysis is applied as the approach focusing on language attitude analysis. It is found that the type of appreciation was dominated by [+valuation] and [+reaction]. The research concluded that Indonesian government portrays fauna in Raja Ampat as its distinctive tourism attraction.

Another study is conducted by Pionery and Isti'anah (2016). They analyzed the modality that is used in Melania Trump and Ivanka Trump's Campaign Speech. The data are taken from the speech in Republican National Convention on July 19th 2016. The study is conducted to find out the type of modality and to reveal the ideologies reflected by using the modality. To find out the type of modality, Systemic Functional Linguistic is used as the theoretical framework and stylistic approach is applied to discuss the type of modality that carries the ideologies. It is found that the type of modality used by Melania Trump were inclination, obligation, potentiality and ability also probability. On the other hand, Ivanka Trump is observed employing the type of modality which are inclination, usuality, potentiality and ability, probability, and obligation. Those modalities reflect that the ideologies carried are commitment and self-promotion.

The other scholars are Olaniyan and Adeniji (2015). They took objective statements segments or the purpose statements for thesis, hypothesis behind particular research paper or work of three hundred of art-based abstracts research articles to explore the discourse function of modality. The study employs Systemic Functional Linguistics as the theoretical framework. It is found that the categories of modality applied in the thesis statements of those research. Possibility modals (might, would, etc) are used to state analytical scope and research goals in the abstract. Necessity modals (must, should, etc) are applied to state analytical scope, to present argument, and to make polite requests. Prediction modals (will, would, etc) are used to state the researcher's research mission in predictive form.

Those studies are similar to another since they used the same theoretical framework, Sys- temic Functional Linguistics with different tools to analyze their objects. It prompts the writers to conduct this research using the same theoretical framework to discover the tourism discourse through the usage of modality. Therefore, the objectives of this research are to analyze the types of modality on the Indonesian website and conclude how modality is used to present Indonesian tourism discourse.

\section{METHODS}

In this research, the object of the study is taken from the destination highlights in Indonesia tourism website, www.indonesia.travel, which is accessed in January 2020. The data includes Medan, Raja Ampat, Bali, Banyuwangi, Bintan Island, Jakarta, Yogyakarta, Bandung, Makassar, and Lombok. The clauses that are used by the destination highlights will be analyzed with a descriptive qualitative approach. A descriptive qualitative approach is used to uncover the complexity and to provide more in-depth examination (Nassaji, 2015). By this approach, it is expected to describe a phenomenon and characteristics.

The clauses are categorized into their types of modality by observing the relationship of Subject-Finite that is employed, as well as involving the modal auxiliaries and modal adverbs, according to the modality of interpersonal metafunction of Halliday's Systemic Functional Linguistics. The summary of the types of modality in all destination highlights are compiled into one table to look at the similarity of tourism discourse. In terms of its modality, the modal adverb as well as auxiliary is analyzed in terms of its context, whether it is modalization or modulation. Then, it is further classified into probability, usuality, obligation, or inclination. Therefore, the modality in the website can be revealed.

\section{RESULT AND DISCUSSION}

There are 87 clauses that contain modals found in ten highlights published in Indonesian Tourism website. It, then, divides into four different types of modal which are probability, usuality, obligation, and inclination. There are 76 clauses that classify as probability presented in $87.36 \%$ of the data. The clauses which employ usuality and inclination have the same number. There are four clauses in each type of modals which is presented in $4.6 \%$ of the data. Obligation are employed in three clauses. It is $3.44 \%$ of the data. 
Types of Modality

Probability

Table 1. Types of Modality in the Highlights

\begin{tabular}{lll}
\hline Types of Modality & Frequency & Percentage \\
\hline Probability & 76 & $87.36 \%$ \\
Usuality & 4 & $4.6 \%$ \\
Inclination & 4 & $4.6 \%$ \\
Obligation & 3 & $3.44 \%$ \\
Total & 87 & $100 \%$ \\
\hline
\end{tabular}

Probability is marked by the modals that show probability and possibility of something happening or being happened. It can be modal auxiliary verbs, or modal adverbs. There are 76 clauses that show probability in text. Probability is the modal with the largest number among the other categories. It is found that it employed the modal auxiliaries which are will, can, could, may, and might. There are nineteen clauses that employs the modal 'will', fifty clauses that uses the modal 'can' and five clauses takes the modal 'may' in the clauses. The first example is the sentence below.

As Bali is located 8 degrees south of the equator, you will find the climate to be the typical tropical, warm and humid all year round with two main distinctive seasons: Dry Season and Rainy Season.

The modal is in the median category. In that sentence, the modal is followed by the verb 'find' and 'you' is the subject of the clause. Therefore, through the sentence, it informs the reader that the climate in Bali is warm and humid along the year which is in dry and rainy season since Bali is located 8 degrees south of the equator. The next example is the sentence below.

In Medan, you can choose a public bus, taxi or becak to get around.

The modal 'can' is a low of probability category. In the sentence, the modal 'can' is followed by the verb 'choose' in which the subject is 'you'. The sentence shows probability and ability to perform an action. The implied meaning of the sentence is that the reader assumes the visitor has the possibility and ability to choose various kinds of transportation to explore the city, Medan. Another example is the sentence below.

You may wish to organize a car and driver for the duration of your stay in Yogyakarta.

That word marks that the sentence is categorized as a possibility in which the word 'may' is a low category. The pronoun 'you' is the subject and the modal 'may' is followed by a verb 'wish'. The word 'may' can be interpreted as 'it is pos- sible that'. Thus, in the sentence, it tries to deliver that it is possible that the visitor organized a car to be rented for some moments.

\section{Usuality}

It is found that four clauses employed modal adjunct which are sometime, usually, and often. Usuality is part of modalization in which it concerns the exchange of "good and services". It is used to show the frequencies or the repetition of something. Below is the example of the usage of modal adjectival "usually" that is used in two different clauses.

When a group of tourists arrived, they usually perform a traditional welcome dance right at the dock and entertained the 'guests' with various Papuan folk songs.

The modal 'usually' marks that the clause is a typical of usuality modality. The word 'usually' is followed by the verb 'perform' and the pronoun 'they' conducts as the subject of the clause. The adverb 'usually' is categorized as median degree. It implies that they, which refers to Arborek people, will perform a traditional welcome dance in a certain time to welcome a group of tourists. The other example is the usage of the modal adverb 'sometimes'.

Distances between points of interest in Jakarta can sometimes be far and might interspersed with traffic.

The word 'sometimes" which is an adverb having a function to signify that the clause is categorized as usuality in terms of the type of modality. It is marked a low category of modality. It gives an emphasis that how far the distance is depends on the traffic. Since it belongs to the low category, the speaker cannot make sure. Another example is the sentence that occupies the modal adverb 'often'.

Ceremonial processions often take up the entire road.

The word that is being employed is 'Often'. It is categorized as a high degree of modality. In the sentence, the subject is 'ceremonial processions' while the predicate the word 'take'. It emphasizes the frequency of doing the ceremonial procession in the entire road. Because it is in median category, it can be assumed that the speaker is quite sure about the opinion.

\section{Inclination}

The percentage of the usage of inclination is the same as usuality. It is found in only four clauses in the text employing the modals that show inclination. Incilantion is a part of modulation which represents the tendency and the capability to do such command, suggestion, demand or advice. On the other hand, it can be said that inclination is used to express willingness in which the word such as 'will' and 'should' are emplo- 
yed. It is found that two out of four clauses employ the modal 'will' and two out of four clauses use the modal 'should'. The first example is the sentence which employed the modal verb 'will'. Just a mere $50 \mathrm{~km}$ from the city, Bantimurung Bulusaraung National Park will greet you with its stunning waterfall and hordes of enchanting butterflies

The modal 'will' that is used in the clause it to show command and willingness to do something. In this case, it is seen that the subject 'Bantimurung Bulusaraung National Park' has a willingness and suggestion to greet the visitor with its waterfall and butterflies that fly around the place. In the clause, 'Bantimurung Bulusaraung National Park' is the subject and the modal is followed by a verb 'greet'. The modal verb 'will' is in median category which means that the speaker is quite enough regarding the information. Another example is the sentence below which employed the modal verb 'should'.

Those who love nature at its finest should walk up the dramatic hills of Tebing Keraton or The Royal (Palace) Cliff, the peak of Moko Hill, Eurad Highland Lembang, or the Stone Garden Citatah.

The modal auxiliary verb 'should' marks that the sentence is categorized as inclination which is a median category. In this sentence, the modal verb is followed by the verb 'walk up' in which the adjective clause 'those who love nature at its finest' is the subject. Thus, it can be inferred that it offers a condition that must be fulfilled by some people who love enjoying nature to walk up the hills.

\section{Obligation}

In this section there are only three clauses that employ the modal auxiliary which are 'maybe', 'will', and 'should'. By using those modal auxiliaries' verbs, the speaker attempts to give command, suggestion, demand or advice. The first example is found in the sentence below.

From strolling through the living museum of The Kraton or The Keraton (Sultan's Palace), to hanging out at the famous Alun Alun, to watching silversmiths produce amazing jewelry at Kotagede and maybe try a splurge shopping up at Malioboro road.

The word 'maybe' is inferred as a suggestion in this sentence. It includes a low category which indicates that it is not quite necessary to do. The modal auxiliary verb 'maybe' is followed by a verb 'try'. Therefore, the sentence means that the readers are suggested to visit Sultan's Palace, Alun Alun, Kotagede and Malioboro. The other example lies in the sentences below.

To get to Raja Ampat you should first take a flight from Jakarta or Makassar to Sorong.
The auxiliary verb 'should' indicates something that is supposed to do. It is in the median category that can be used when the speaker lacks authority to impose the obligation. The word is followed by the verb 'take' and the pronoun 'you' plays as the subject which is associated as the reader. The sentence can be inferred that the readers are supposed to take flight from certain city to go to Sorong. Therefore, the sentence states a command for the readers. Another example is the sentence which employed the word 'will'.

So you'll need to be patient with some traffic jams.

The word 'will' in this sentence is employed to show obligation. It expresses medium obligation which means an advice for the subject, you. The modal auxiliary verb 'will' is followed by the verb 'need' and 'you' is the subject which refers to the readers. The sentence carries a meaning which the readers are given an advice to be patient due to the traffic jams.

\section{Tourism Discourse seen from Modality}

Modality is used to express the attitude of the speaker about what is said, and is marked by the auxiliaries in which it is covering such notions as probability, usuality, obligation, and inclination. The official website incorporates tourism discourse through multiple modalities to exploit patterns and functions of linguistics which nations use to promote themselves (Hallet \& KaplanWeinger). On the destination highlights of the official website of Indonesia tourism, the tourism discourse that is discovered are itineraries and access, place to play, and authenticity. There are 37 clauses which show the itineraries and access tourism discourse, presented in $42.53 \%$ of the data. The second largest is the place to play discourse with 35 clauses, presented in $40.23 \%$ of the data. The last one is the authenticity with 15 clauses which presented in $17.24 \%$ of the data.

Table 2. Types of tourism discourse in the Highlights

\begin{tabular}{lll}
\hline Tourism discourse & Frequency & Percentage \\
\hline Itineraries and access & 37 & $42.53 \%$ \\
Place to play & 35 & $40.23 \%$ \\
Authenticity & 15 & $17.24 \%$ \\
Total & 87 & $100 \%$ \\
\hline
\end{tabular}

\section{Itineraries and Access}

Itineraries and access discourse hold the largest percentage of the discourse in the data. Itinerary includes means of transport, safety, some information on the potential future plans and how travel will benefit the tourists and the people 
they come in contact with; and how important travel was to the tourists (Jaworski \& Pritchard, 2005). With this tourism discourse, it shows that the website, or the government that wrote the website, wants to provide clear information for the tourist's comfort and easy life throughout their stay. The example of the itineraries and access discourse is explained below.

In Medan, you can choose a public bus, taxi or becak to get around.

In the above example, the website tries to give the readers information of the vehicle they are able to choose from when they are in Medan. To make sure that the tourists have a comfortable time in Medan, the website attempts to exchange information on what kind of transportation they can use and is available for them. The modality that is used is probability, in the form of the modal auxiliary 'can'. In this context, the website hands the choice to the readers and at the same time, they give themselves a chance that they might be wrong, as the probability modals are used to show how likely it is to be true. The website cannot make sure what transportation methods are available so it offers information on the various transportation methods.

People who visit Jakarta, usually take time to stop by the neighboring Bogor, famous for its Botanical Garden and highlands getaway in the Puncak area.

Another example of itineraries and access discourse is the above example. In the example, the website means to offer an itinerary choice based on what most people that come to Jakarta do. The usuality modal that is used is "usually" which indicates a medium value modal. The readers are offered information on what itineraries they should make to fully enjoy Jakarta. The website intends to channel the tourist gaze towards the destinations and services that are part of their intended itinerary (Jaworski and Pritchard, 2005). The information that is given is intended to help the tourists who have no fixed itinerary and timetable.

To get to Raja Ampat you should first take a flight from Jakarta or Makassar to Sorong.

As Raja Ampat is located in Papua, a place with less access than in Java, the website intends to give the right information about what transportation method the tourist should do to access Raja Ampat. It is important to include how to access the place for the potential tourists. It strikes a balance between promoting tourism by giving clear information on how to come to the place while shielding potential travelers from danger (Hallett and Kaplan-Weinger).

\section{Place to play}

The tourism discourse with the second highest percentage is "place to play". Places to play are places involved in producing distinctions of taste resulting from consuming, and anticipating the consumption, of an incredible array of goods and services (Jaworski \& Pritchard, 2005). The places that the website introduces play a high role in constructing the tourists' understanding of the country (Jaworski \& Pritchard, 2005). Therefore, "place to play" discourse is highly important as it contains the means to promote the tourism sites.

The example is below.

Green Bay or Sarongan Pesanggaran will astound you with its waters, which are green on the shores and turn to blue, as the water flows further away from the beach line.

The offered place to play in the sentence is the landscape of Green Bay or Sarongan Pesanggaran. It is described with favorable words that promote its beautiful waters which the website believes is astounding, as proven in their choice of modal. The notion of landscape emphazises leisure, relaxation and visual consumption by visitors (Jaworski \& Pritchard, 2005). The Green Bay is considered as a unique virgin beach that has a tropical atmosphere and white sands. The readers or the potential tourists are given the portrayal of the landscapes in hope that they will turn into real tourists.

Those who love nature at its finest should walk up the dramatic hills of Tebing Keraton or The Royal (Palace) Cliff, the peak of Moko Hill, Eurad Highland Lembang, or the Stone Garden Citatah.

Potential tourists are once again offered the portrayal of the landscape, with the addition of the calling to the "nature enthusiast" as mentioned in the phrase "those who love nature at its finest". This addition will invite people who consider themselves as part of the group of people that love nature. The promotion of the tourism site is increasingly generated not by commerce but by collective enthusiasts (Jaworski \& Pritchard, 2005). Therefore, the website uses the enthusiasm of nature lovers to come to the place.

\section{Authenticity}

This tourism discourse has the lowest percentage in the data. Authenticity deals with goods and services that are distinctive in some heritage tourism's design, implementation and experience (Jaworski \& Pritchard, 2005). Therefore, in the website, the authenticity tourism discourse can be found through Indonesian traditional transportation, food and beverages, performances, and cul- 
tural heritage. The example is

For a beverage, you can try the Jamu, a natural herb mix beverage based on ancient tradition used for natural remedies.

The authenticity that is offered is jamu, an authentic Indonesian natural remedy, that has already existed since ancient time. It is considered as part of alternative medicine that is used for natural remedies. Using this, the website intends to use the authenticity of jamu to show an interesting reason why the potential tourists should go to Indonesia.

When a group of tourists arrived, they usually perform a traditional welcome dance right at the dock and entertained the 'guests' with various Papuan folk songs.

The authenticity that is offered is the traditional welcome dance with various Papuan folk songs. This dance performance is done right at the dock and is entertaining to watch. The usuality modal that is used is "usually" which indicates a modal with medium value, showing that most of the time they performed the traditional welcome dance, though the website cannot make sure that they will always perform the dance upon the tourists' arrival. The dance is part of Indonesian cultural heritage that is special to the region of Papua. In order to enjoy the welcoming dance, the potential tourists should come to Papua and be their "guests".

\section{CONCLUSION}

The website employs modality realized in 87 clauses which is probability, usuality, inclination, and obligation. From the data, it can be seen that the highest percentage being probability and the lowest being obligation. The official website of Indonesian tourism shows three tourism discourses: itineraries and access, place to play, and authenticity.

It is found that medium and low category dominate the usage of modality in those ten highlights. It can be inferred that in delivering content, the website is not quite sure about the information. The high number of probability and low number of obligations emphasize the discourse of itineraries and access that the website intends to let the readers get all the facts and information about the place that they are going to visit in order to make sure of their safety and comfort during their travel. Even though it contains promotion purposes, the website mainly prioritizes to provide information, rather than advertising aspect. It can be concluded that the website serves as a source of information that potential tourists and readers can rely on, but further research on the destination is still needed, particularly on the ideational and textual metafunctions of language.

\section{REFERENCES}

Chairiyah, N. (2013). Taxonomic Contribution For Ecotourism Development In Indonesia. Journal of Indonesian Tourism and Development Studies, 1(3), 115122.

Cholik, M. A., \& SE, M. (2017). The development of tourism industry in Indonesia: Current problems and challenges. European Journal of Research and Reflection in Management Sciences, 5(1), 49-59.

Dewi, M. P., Rahmatunnisa, M., Sumaryana, A., \& Kristiadi, J. B. (2018). Ensuring Service Quality in Education for Indonesia's Sustainable Education. Journal of Social Studies Education Research, 9(4), 65-81.

Pranita, D. (2018). Digitalization: The way to tourism destination's competitive advantage (case study of Indonesia Marine Tourism). The 2nd International Conference on Vocational Higher Education (ICVHE) 2017 "The Importance on Advancing Vocational Education to Meet Contemporary Labor Demands" (pp. 243-253). KnE Social Sciences.

Downing, A., \& Locke, P. (2006). English Grammar A University Course Second Edition. New York: Routledge.

Eggins, S. (2004). An Introduction to Systemic Functional Linguistics Second Edition. London: Continuum international Publishing Group.

Endarto, I. T. (2017). Systemic functional linguistics: A brief introduction. Forum Diskusi Basantara Yogyakarta. Forum Diskusi Basantara Yogyakarta. Retrieved from www.academia.edu/34037346/ Systemic_Functional_Linguistics_A_Brief_Introduction

Hallett, R. W., \& Kaplan-Weinger, J. (2010). Official tourism websites: a discourse analysis perspective (Vol. 23). Channel View Publications.

Halliday, M., \& Matthiessen, C. M. (2014). Halliday's introduction to functional grammar (4th ed.). Routledge.

Isti'anah, A. (2019, August). Appreciation for Raja Ampat in the Official Website of Indonesian Tourism: Ecolinguistic Study. In Fifth Prasasti International Seminar on Linguistics (PRASASTI 2019). Atlantis Press.

Jack, G., \& Phipps, A. (2005). Tourism and intercultural exchange why tourism matters. Channel View Publications.

Jaworski, A., \& Pritchard, A. (2005). Discourse, communication and tourism. Channel View Publication.

Manggala, S. A. (2017). The Linguistic Choices in Reproducing Ideology of a Local Folktale. In Fifth International Seminar on English Language and Teaching (ISELT 2017). Atlantis Press.

Nassaji, H. (2015). Qualitative and descriptive research: Data type versus data analysis. Language Teaching Research, 129-132. 
Olaniyan, K. K., Adeolu, \& Adenji. (2015). Modality in statement of objectives in arts-based research article abstract. British Journal of English Linguistics, 42-51.

Pionery, H., \& Isti'anah, A. (2017). Modality Analysis in Melania Trump's and Ivanka Trump's Campaign Speeches in Republican National Convention, July 19th, 2016. Journal of Language and Literature, 17(1), 24-35.
Suparwoko. (2011). Community-based Approach to Tourism in Indonesia. Deepublish.

Syamsidar, S., Yatmikasari, I., \& Nurrachman, D. (2019). Mood and Modality in Soekarano's 1955 Speech. Paradigm, 2(2), 109-120.

Yuyun, I. (2010). A mood and modality analysis of arguments in senior high school debating. English Studies Center for Studies on Language and Culture (pp. 161-166). Atma Jaya Catholic University. 